\title{
Development of a Need-based Interventional Skin Care Protocol on Incontinence-associated Dermatitis among Critically Ill Patients
}

\author{
Prashant Sharma ${ }^{1}$, Latha Sambatra ${ }^{2}$, Rajesh K Sharma $^{3} \mathbb{C}$
}

\begin{abstract}
Background: Incontinence-associated dermatitis (IAD) is a potentially serious skin injury that can lead to pressure ulcers (PUs). Many studies have indicated the need for evidence to find the most effective skin care protocol to reduce the incidence and severity of IAD in critically ill patients.

Aim and objective: To develop a need-based interventional skin care protocol on IAD after identifying the risk of developing IAD in critically ill patients and by assessing the nurse's knowledge and practice on IAD.

Materials and methods: Quantitative research approach with an exploratory research design was adopted in the study. A total of 40 staff nurses and 100 patients were included. To assess the knowledge of staff nurses regarding IAD, a knowledge questionnaire was administered and the IAD prevention practice among staff nurses was assessed with the help of an observation checklist. The risk of IAD among 100 critically ill patients was observed by the investigator, using a perineal risk assessment tool. The obtained data were analyzed by using descriptive and inferential statistics. The protocol was developed by the researcher and it was validated by 5 experts.

Results: The results revealed that most of patients (60\%) had a high risk for development of IAD. Most of the nurses had poor knowledge (40\%) and had poor practice in assessment, perineal area, and prevention of infection area. Hence considering all these aspects, a protocol was developed. Conclusion: The researchers developed a need-based skin care protocol to decrease the development of IAD.

Keywords: Critically ill patients, Incontinence-associated dermatitis (IAD), Need-based interventional skin care protocol.

Indian Journal of Critical Care Medicine (2021): 10.5005/jp-journals-10071-23716
\end{abstract}

\section{INTRODUCTION}

Incontinence is characterized by an uncontrolled loss of urine as well as stool/feces at an inappropriate time or in an inappropriate place. Incontinence is not an illness; however, it may be a side effect of a hidden disorder. ${ }^{1}$

Incontinence can range from a steady or discontinuous spilling of a small amount of urine to an infrequent and uncontrolled release of vast volumes of body waste. Although incontinence is not thought to be part of a typical maturing process, age-related changes are the predisposing factors and do make incontinence more probable in older people. Different conditions that can cause incontinence are spinal cord injuries, dementia, birth defects, and childbearing. ${ }^{1}$

Incontinence-associated dermatitis (IAD) is an inflammatory skin condition that happens when the skin is presented to urine or stool and leads to a secondary infection, pain, and skin sores. IAD incidence rates fluctuate from 5.6 to $50 \%$, and the prevalence rates differ from 3.4 to $25 \%$. Incontinence usually has many causes, is not completely understood, and includes psychological and physiological components. $^{2}$

Recent evidence indicates that approximately $20 \%$ of acute care patients are incontinent and that $42.5 \%$ of incontinent patients have some type of a skin injury. Although the pathophysiology of IAD is not completely understood, disturbance of the skin's acid mantle as a protective barrier is thought to play a key role. It is a daily challenge for the health professionals in hospitals, nursing homes, and community care to maintain a healthy skin in patients with incontinence. ${ }^{2}$
${ }^{1}$ Department of Medical Surgical Nursing, Pal College of Nursing and Medical Sciences, Haldwani, Uttarakhand, India

${ }^{2}$ Department of Medical Surgical Nursing, Nitte (Deemed to be University), Nitte Usha Institute of Nursing Sciences, Mangaluru, Karnataka, India

${ }^{3}$ Department of Critical Care Nursing, Himalayan College of Nursing, Swami Rama Himalayan University, Dehradun, Uttarakhand, India

Corresponding Author: Prashant Sharma, Department of Medical Surgical Nursing, Pal College of Nursing and Medical Sciences, Haldwani, Uttarakhand, India, Phone: +91 7014863070, e-mail: prashantsharma293@gmail.com

How to cite this article: Sharma P, Latha S, Sharma RK. Development of a Need-based Interventional Skin Care Protocol on Incontinenceassociated Dermatitis among Critically III Patients. Indian J Crit Care Med 2021;25(2):158-165.

Source of support: Nil

Conflict of interest: None

Urinary incontinence is a worldwide medical issue influencing $8.2 \%$ of the 2008 total population (4.3 billion). ${ }^{2}$

Fecal incontinence (FI) is thought to be very common, but much under-reported due to embarrassment. ${ }^{10}$ It affects people of all ages, but is more common in older adults (but it should not be considered a normal part of aging). ${ }^{11}$ Females are more likely to develop it than males (63\% of those with Fl aged 30 may be females). ${ }^{10}$ In 2014, the National Center for Health Statistics reported that one of every six seniors in the United States who lived in their own home or apartment 
had FI. Men and women were equally affected. ${ }^{9}$ And $45-50 \%$ of people with FI had severe physical and/or mental disabilities. ${ }^{10}$

\section{Materials and Methods}

In this study, a quantitative research approach was adopted. Research design was an exploratory research design. The study was conducted in KS Hegde Hospital, Mangaluru. One hundred critically ill patients and 40 staff nurses of KS Hegde Hospital, Mangaluru, were included. Purposive sampling technique was used. For data collection, three tools were used. Perineal risk assessment tool was used to assess the risk of IAD among critically ill patients. Knowledge questionnaire and observation checklist were used to assess the knowledge and practice about IAD among staff nurses. Tool validity was done by 11 experts. To check the reliability, Cronbach's alpha method was used.

\section{Results}

\section{Section-1: Assessment of Risk of IAD among Patients}

In this study, the risk of IAD was assessed for all of the 100 patients. The results revealed that $91 \%$ had soft stool with or without urine, followed by formed stool $7 \%$ and liquid stool with or without urine $2 \%$. Most of the subjects (89\%) had changed linen/pad at least every eight hours, $10 \%$ four hourly, and $1 \%$ two hourly. Of the study population, $48 \%$ had clear and intact skin; among the rest of the subjects, $40 \%$ had erythema/dermatitis with or without candidiasis and $12 \%$ had denuded/eroded skin with or without dermatitis, and $49 \%$ had three or more contributing factors (Table 1).

In this study, Figure 1 shows that among the 100 subjects, $60 \%$ had high risk and $40 \%$ had low risk of IAD.

\section{Section-2: Assessment of Knowledge and Practice about IAD among Staff Nurses}

In this study, among the 40 staff nurses, $80 \%$ was aware that the top layer of the epidermis is stratum corneum, $72.5 \%$ had knowledge that the $\mathrm{pH}$ of the skin is normally acidic, $67.5 \%$ had knowledge that IAD is caused due to exposure to friction, and $67.5 \%$ had knowledge that IAD associated with $\mathrm{FI}$ tends to occur in the anal region and buttocks (Table $2 \mathrm{~A}$ ).

The knowledge score ranged between 3 and 17 with a mean of $9.05 \pm 1.43$. All the 20 knowledge questions were assigned a value of either one for the correct answer or zero for the wrong answer. Then the total score had been obtained, and the scores were divided into three subgroups according to the level of perceived knowledge of the subjects. In this, concept of percentile method was used.

$$
\begin{aligned}
& >\mathrm{P}_{1}-\mathrm{P}_{33} \text { as poor knowledge (3-8), } \\
& >\mathrm{P}_{34}-\mathrm{P}_{67} \text { as average knowledge (9-11), } \\
& >\mathrm{P}_{68}-\mathrm{P}_{100} \text { as good knowledge (12-17) (Fig. 2). }
\end{aligned}
$$

Figure 2 shows that among the 40 staff nurses, $40 \%$ had poor level of knowledge about IAD followed by $32.5 \%$ with average knowledge and $27.5 \%$ with good knowledge.

In this study, Table 2B shows that among the 40 staff nurses in the assessment area, majority performed handwashing, provided privacy to the patient, and maintained input-output chart. In the perineal area, majority were separating the legs of the patient and

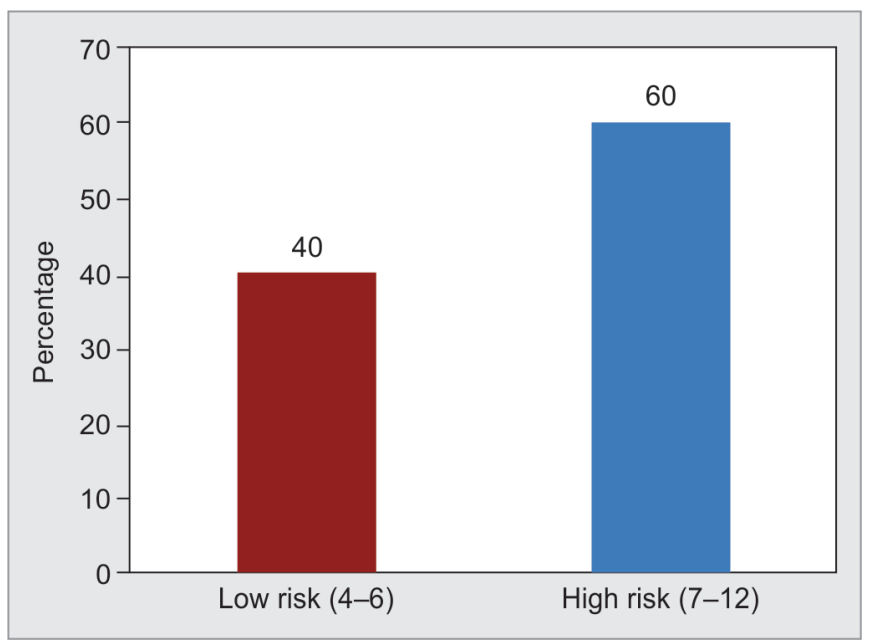

\begin{tabular}{|c|c|c|}
\hline IAD risk $(n=100)$ & & Frequency \\
\hline \multirow[t]{3}{*}{ The intensity of irritant and type and consistency of irritant } & Formed stool and/or urine & 7 \\
\hline & Soft stool with or without urine & 91 \\
\hline & Liquid stool with or without urine & 2 \\
\hline \multirow{3}{*}{$\begin{array}{l}\text { Duration of irritant and amount of time that skin is exposed } \\
\text { to the irritant }\end{array}$} & Linen/pad changes at least every 8 hours & 89 \\
\hline & Linen/pad changes at least every 4 hours & 10 \\
\hline & Linen/pad changes at least every 2 hours & 1 \\
\hline \multirow[t]{3}{*}{ Perineal skin condition and skin integrity } & Clear and intact & 48 \\
\hline & Erythema/dermatitis with or without candidiasis & 40 \\
\hline & Denuded/eroded skin with or without dermatitis & 12 \\
\hline \multirow{3}{*}{$\begin{array}{l}\text { Contributing factors: low albumin, antibiotics, tube feeding, } \\
\text { or other }\end{array}$} & $0-1$ contributing factors & 15 \\
\hline & 2 contributing factors & 36 \\
\hline & 3 or more contributing factors & 49 \\
\hline
\end{tabular}

Fig. 1: Level of risk of IAD among subjects

Table 1: Assessment of risk of IAD among patients 
Table 2A: Assessment of knowledge about IAD among staff nurses

\begin{tabular}{|c|c|c|}
\hline Knowledge $(n=40)$ & Frequency & Percentage \\
\hline The top layer of the epidermis is the stratum corneum & 32 & 80 \\
\hline The $\mathrm{pH}$ of the skin normally is acidic & 29 & 72.5 \\
\hline $\begin{array}{l}\text { The primary layer that serves as a protective barrier to shield internal tissues from exposure to toxins and } \\
\text { bacteria is the stratum corneum }\end{array}$ & 11 & 27.5 \\
\hline Which of the following is particularly harmful to the skin's barrier function? Fecal enzymes & 14 & 35 \\
\hline Reported prevalence rates of IAD vary from 5.6 to $50 \%$ & 19 & 47.5 \\
\hline Skin damage from incontinence is dependent on all of the above & 19 & 47.5 \\
\hline $\begin{array}{l}\text { Which of the following statements about urinary incontinence is not true? Men are more susceptible to IAD } \\
\text { due to their anatomical structure }\end{array}$ & 18 & 45 \\
\hline Which of the following is the most important risk factor for IAD in a patient with incontinence? Liquid stools & 21 & 52.5 \\
\hline $\begin{array}{l}\text { Incontinent women are more likely than men to develop IAD during bed rest because in females, urethra is } \\
\text { short and much less supported than in males }\end{array}$ & 20 & 50 \\
\hline Factors associated with the development of IAD include all except the use of tight clothing & 8 & 20 \\
\hline IAD is caused due to exposure to friction & 25 & 67.5 \\
\hline The major etiologic factors for IAD are exposure to urine and stool & 20 & 50 \\
\hline IAD lesions are characterized as a wet-macerated appearance of skin along with. superficial erosion & 17 & 42.5 \\
\hline IAD that is associated with fecal incontinence tends to occur in the anal region and buttocks & 27 & 67.5 \\
\hline The typical pattern of IAD lesions are. bottom-up injuries & 11 & 27.5 \\
\hline $\begin{array}{l}\text { Which IAD assessment tool allows the clinician to match a patient's clinical presentation with the photographs } \\
\text { for appropriate interventions? IAD intervention tool }\end{array}$ & 9 & 22.5 \\
\hline $\begin{array}{l}\text { The first line of defense for preventing IAD in an incontinent patient is identify and treat the causes of } \\
\text { incontinence }\end{array}$ & 16 & 40 \\
\hline Which of the following is not an effective prevention or management measure of IAD? Use of cotton clothes & 12 & 30 \\
\hline $\begin{array}{l}\text { Following an episode of incontinence, a structured skin-cleansing regimen should include gentle cleansing, } \\
\text { moisturizing, and use of skin protectant }\end{array}$ & 20 & 50 \\
\hline Which is a common complication of IAD? All of the above & 13 & 32.5 \\
\hline
\end{tabular}

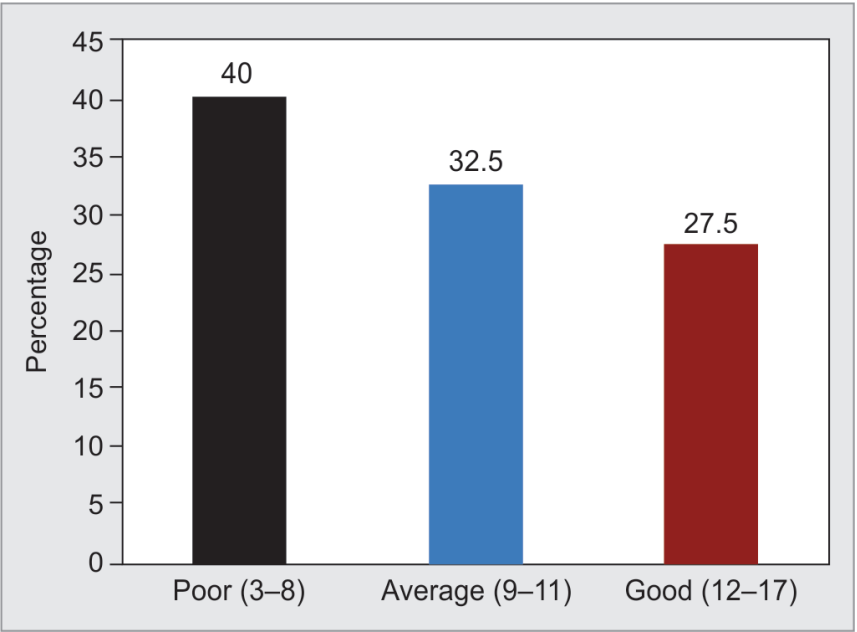

Fig. 2: Level of knowledge about IAD among staff nurses provided privacy to the patient; in the prevention of infection area, majority were changing indwelling catheters within seven days.

\section{Section-3: Association between Baseline Knowledge and Practice with Selected Variables}

In this study, to find the association between baseline knowledge score and demographic characteristics among staff nurses, Fisher exact and chi-square tests were used. The obtained ' $p$ ' values were $>0.05$ and hence there was no association between the demographic characteristics and the knowledge score at the $5 \%$ level of significance (Table $3 \mathrm{~A}$ ).

In this study, Table 3B revealed that Fisher exact test was used to find the association between the reported practices and the educational status of the staff nurses. The obtained ' $p$ ' value was $<0.05$ only for "item no. 12, 13, and 14." Hence, these practices were associated with the level of educational status, and for all other comparisons, the ' $p$ ' values were $>0.05$ and hence there was no association between those practices and the educational status. 
Table 2B: Assessment of practice about IAD among nurses

\begin{tabular}{|c|c|c|}
\hline Practice $(n=40)$ & Frequency & Percentage \\
\hline \multicolumn{3}{|l|}{ Assessment } \\
\hline 1 Performs handwashing & 40 & 100 \\
\hline 2 Assesses the risk of IAD within four hours of admission (as evidenced by records) & 27 & 67.5 \\
\hline 3 Assesses the skin and risk of IAD thrice daily (as evidenced by records) & 11 & 27.5 \\
\hline 4 Maintains intake-output chart & 40 & 100 \\
\hline 5 Monitors weight daily (as evidenced by records) & 4 & 10 \\
\hline 6 Notes the volume and character of urine and records observations carefully & 40 & 100 \\
\hline \multicolumn{3}{|l|}{ Perineal care } \\
\hline 1 Washes hands before and after procedure & 40 & 100 \\
\hline 2 Provides privacy to the patient & 40 & 100 \\
\hline 3 Separates the legs of the patient & 40 & 100 \\
\hline 4 Observes the perineal area & 39 & 97.5 \\
\hline 5 Cleanses the perineal area thoroughly & 17 & 42.5 \\
\hline 6 Cleanses the skin with a washcloth & 20 & 50 \\
\hline 7 Uses normal saline to clean the perineal area & 14 & 35 \\
\hline 8 Wipes from upside to downwards & 5 & 12.5 \\
\hline 9 Dries the skin properly & 17 & 42.5 \\
\hline 10 Documents the procedure & 36 & 90 \\
\hline \multicolumn{3}{|l|}{ Prevention of infection } \\
\hline 1 Washes hands before and after procedure & 40 & 100 \\
\hline 2 Avoids skin wetness by keeping the area dry and clean & 23 & 57.5 \\
\hline 3 Replaces the dirty linens with clean ones & 35 & 87.5 \\
\hline 4 Uses clean washcloth every time & 16 & 40 \\
\hline 4 Changes diaper frequently as necessary & 25 & 62.5 \\
\hline 5 Reports any signs of infection promptly & 39 & 97.5 \\
\hline 6 Documents the procedure & 37 & 92.5 \\
\hline 7 Changes indwelling catheters within seven days & 40 & 100 \\
\hline
\end{tabular}

Table 3A: Association between baseline knowledge and demographic characteristics among staff nurses

\begin{tabular}{|c|c|c|c|c|c|}
\hline & & \multicolumn{2}{|c|}{ Median } & \multirow[b]{2}{*}{ Statistical test } & \multirow[b]{2}{*}{ ' $p$ 'value } \\
\hline \multicolumn{2}{|c|}{ Knowledge $(n=40)$} & $\leq 10$ & $>10$ & & \\
\hline \multirow[t]{2}{*}{ Gender } & Male & 0 & 1 & \multirow{2}{*}{$\begin{array}{l}0.4 \\
\text { (Fisher exact) }\end{array}$} & \multirow[t]{2}{*}{0.4} \\
\hline & Female & 24 & 15 & & \\
\hline \multirow{2}{*}{$\begin{array}{l}\text { Educational } \\
\text { status }\end{array}$} & Diploma & 8 & 6 & \multirow{2}{*}{$\begin{array}{l}0.073 \\
\text { (Chi-square) }\end{array}$} & \multirow[t]{2}{*}{0.787} \\
\hline & Graduate & 16 & 10 & & \\
\hline
\end{tabular}

\section{Section-4: Association between Risk of IAD and Selected Variables}

In this study, to find the association between the risk of IAD and the demographic characteristics among critically ill patients, likelihood ratio and chi-square test were used. If the obtained ' $p$ ' values were $<0.05$, then there was an association of age and educational status with risk of $I A D$, and there was no association of gender, religion, and marital status with risk of IAD (Table 4)

\section{Discussion}

\section{Section-1: Assessment of Risk of IAD among Patients}

In this study, the results revealed that most of the patients are at high risk of IAD. Ninety-one percent of them had a soft stool with or without urine. Majority of the subjects (89\%) had changed linen/pad at least eight hourly. Forty-eight percent of the subjects had a clear and intact skin; $40 \%$ had erythema/dermatitis with or without candidiasis and the rest of the subjects (12\%) had denuded/ eroded skin with or without dermatitis, and $49 \%$ had three or more contributing factors.

According to the article published by "Mikel Gray," it explores that the risk of IAD or perineal skin damage is the greatest when the absorptive product becomes saturated with urine or when the skin remains occluded under a wet-absorptive product over an extended period of time. ${ }^{3}$ 
Table 3B: Association between practice and educational status among staff nurses

\begin{tabular}{|c|c|c|c|c|c|c|}
\hline \multirow[b]{2}{*}{$n=40$} & \multicolumn{2}{|c|}{ Diploma } & \multicolumn{2}{|c|}{ Graduate } & \multirow[b]{2}{*}{ Fisher exact test } & \multirow[b]{2}{*}{ 'p'value } \\
\hline & $f$ & $\%$ & $F$ & $\%$ & & \\
\hline Q3. Assesses the risk of IAD within four hours of admission (as evidenced by records) & 9 & 22.5 & 18 & 45 & 0.0201 & 0.751 \\
\hline Q4. Assesses the skin and risk of IAD thrice daily (as evidenced by records) & 3 & 7.5 & 8 & 20 & 0.0725 & 0.523 \\
\hline Q5. Avoids skin wetness by keeping the area dry and clean & 11 & 27.5 & 12 & 30 & 0.189 & 0.48 \\
\hline Q7. Monitors weight daily (as evidenced by records) & 2 & 5 & 2 & 5 & 0.3847 & 0.516 \\
\hline Q10. Observes the perineal area & 14 & 35 & 25 & 62.5 & 0.0089 & 0.349 \\
\hline Q11. Cleanses the skin with a washcloth & 7 & 17.5 & 13 & 32.5 & 0.0635 & 1.000 \\
\hline Q12. Wipes from upside to downside & 4 & 10 & 1 & 2.5 & 0.1521 & $0.027^{*}$ \\
\hline Q13. Dries the skin properly & 10 & 25 & 7 & 17.5 & 0.1557 & $0.007^{*}$ \\
\hline Q14. Uses clean washcloth every time & 2 & 5 & 14 & 35 & 0.0007 & $0.015^{*}$ \\
\hline Q15. Replaces the dirty linens with clean ones & 12 & 30 & 23 & 57.5 & 0.0533 & 0.804 \\
\hline Q16. Documents the procedure & 14 & 35 & 22 & 55 & 0.0364 & 0.055 \\
\hline Q17. Changes diaper frequently as necessary & 10 & 25 & 15 & 37.5 & 0.0938 & 0.392 \\
\hline Q19. Cleanses the perineal area thoroughly & 6 & 15 & 11 & 27.5 & 0.087 & 0.973 \\
\hline Q20 Uses normal saline to clean the perineal area & 5 & 12.5 & 9 & 22.5 & 0.1993 & 0.945 \\
\hline Q22. Reports any signs of infection promptly & 14 & 35 & 25 & 62.5 & 0.0089 & 0.349 \\
\hline Q23. Documents the procedure & 14 & 35 & 23 & 57.5 & 0.0239 & 0.099 \\
\hline
\end{tabular}

*Indicates significantly

Table 4: Association between risk of IAD and demographic characteristics

\begin{tabular}{|c|c|c|c|c|c|}
\hline \multirow[b]{2}{*}{ IAD risk $(n=100)$} & & \multicolumn{2}{|c|}{ Risk } & \multirow[b]{2}{*}{ Statistical test } & \multirow[b]{2}{*}{ 'p'value } \\
\hline & & $4-6$ & $7-12$ & & \\
\hline \multirow[t]{4}{*}{ Age (in years) } & $21-40$ & 10 & 6 & \multirow{4}{*}{$\begin{array}{l}14.231 \\
\text { (Likelihood ratio) }\end{array}$} & \multirow[t]{4}{*}{$0.003^{*}$} \\
\hline & $41-60$ & 24 & 25 & & \\
\hline & $61-80$ & 6 & 27 & & \\
\hline & $>80$ & 0 & 2 & & \\
\hline \multirow[t]{2}{*}{ Gender } & Male & 22 & 36 & \multirow{2}{*}{$\begin{array}{l}0.246 \\
\text { (Chi-square test) }\end{array}$} & \multirow[t]{2}{*}{0.620} \\
\hline & Female & 18 & 24 & & \\
\hline \multirow[t]{4}{*}{ Educational status } & No formal education & 6 & 21 & \multirow{4}{*}{$\begin{array}{l}8.393 \\
\text { (Likelihood ratio) }\end{array}$} & \multirow[t]{4}{*}{$0.039^{*}$} \\
\hline & Primary education & 14 & 24 & & \\
\hline & High school & 16 & 11 & & \\
\hline & PUC & 4 & 4 & & \\
\hline \multirow[t]{3}{*}{ Religion } & Hindu & 35 & 44 & \multirow{3}{*}{$\begin{array}{l}3.619 \\
\text { (Likelihood ratio) }\end{array}$} & \multirow[t]{3}{*}{0.164} \\
\hline & Christian & 1 & 6 & & \\
\hline & Muslim & 4 & 10 & & \\
\hline \multirow[t]{3}{*}{ Marital status } & Married & 34 & 43 & \multirow{3}{*}{$\begin{array}{l}4.75 \\
\text { (Likelihood ratio) }\end{array}$} & \multirow[t]{3}{*}{0.093} \\
\hline & Unmarried & 3 & 3 & & \\
\hline & Widow & 3 & 14 & & \\
\hline
\end{tabular}

*Indicates significantly 
Protocol for IAD Care In Hospital for critically III patient (Bed ridden Patients)

\begin{tabular}{|c|c|c|c|}
\hline $\begin{array}{l}\text { Assessment of patient } \\
\text { with urinary }+1-\text { fecal } \\
\text { incontinence }\end{array}$ & Category & $\begin{array}{l}\text { Sign \& } \\
\text { symptoms }\end{array}$ & Treatment \\
\hline $\begin{array}{l}\text { Assess and document the } \\
\text { perinea! area skin daily in } \\
\text { high risk and incontinent } \\
\text { individuals with help of } \\
\text { Perineal Risk Assessment } \\
\text { Tool (PAT) \& } \\
\text { Incontinence-associated } \\
\text { dermatitis and its severity } \\
\text { (LADS) instrument tools. }\end{array}$ & $\begin{array}{l}\text { Category-0 } \\
\text { Skin } \\
\text { Condition- } \\
\text { Intact Skin } \\
\text { without } \\
\text { redness in } \\
\text { high risk } \\
\text { patient) }\end{array}$ & $\begin{array}{l}\text { Skin is } \\
\text { Normal }\end{array}$ & $\begin{array}{l}\text { Skin care: Cleanse, moisturize, } \\
\text { and protect } \\
\text { - Select a pH-balanced skin } \\
\text { cleanser (one whose pH range } \\
\text { approximates the acid mantle of } \\
\text { healthy skin). } \\
\text { - Gentle cleansing with soft cloth. } \\
\text { - Routine use of a moisturizer } \\
\text { is recommended } \\
\text { - To replace intercellular lipids } \\
\text { - Promote moisture barrier } \\
\text { function of the skin. } \\
\text { - Avoid using diapers and adult } \\
\text { briefs in bed. } \\
\text { - Anti-inflammatory products should } \\
\text { not be used for routine treatment of IAD. } \\
\text { - Do not use antimicrobials for the } \\
\text { routine treatment of IAD. }\end{array}$ \\
\hline $\begin{array}{l}\text { Assess and document } \\
\text { the perinea! area skin } \\
\text { daily in high risk and } \\
\text { incontinent individuals } \\
\text { with help of PAT \& IADS } \\
\text { tools. }\end{array}$ & $\begin{array}{l}\text { Category-1 } \\
\text { (Skin condition: } \\
\text { Intact skin with } \\
\text { Mild erythema) }\end{array}$ & $\begin{array}{l}\text { Presence of } \\
\text { Redness } \\
\text { with or } \\
\text { without } \\
\text { edema }\end{array}$ & $\begin{array}{l}\text { Treatment, management \& } \\
\text { Prevention will be as per } \\
\text { Category } \\
-0 \text { along with following: } \\
\text { - Position the person semi } \\
\text { prone to } \\
\text { expose affected skin to air. } \\
\text { - Antifungal products should } \\
\text { be used only } \\
\text { when a cutaneous fungal } \\
\text { rash is present. }\end{array}$ \\
\hline
\end{tabular}

Fig. 3: Protocol on prevention and management of IAD.

\section{Section-2: Assessment of Knowledge and Practice about IAD among Staff Nurses}

This study stated that among the 40 staff nurses, $40 \%$ had a poor level of knowledge about IAD followed by $32.5 \%$ with average knowledge, and $27.5 \%$ with good knowledge.

A similar cross-sectional study was conducted in the year 2015 by "Abede and Daniel" taking 217 nurses, and this study revealed that majority (61\%) of them had above-average level of knowledge about skin integrity maintenance practice. ${ }^{4}$
Results revealed that among the 40 participants, majority followed handwashing, provided privacy to the patient, maintained input-output chart, separated the legs of the patient, noted the volume and character of urine, recorded observations carefully, and changed indwelling catheters within seven days.

A supportive cohort study conducted from the year 2011-2015 by "Almunzer Zakaria" et al. taking more than 2000 hospital staff revealed that majority of the participants (94\%) followed the handwashing techniques. ${ }^{5}$ 


\begin{tabular}{|c|c|c|c|}
\hline $\begin{array}{l}\text { Assess and document the } \\
\text { perineal area skin daily in } \\
\text { high risk/category } 1 \text { and } \\
\text { incontinent individuals } \\
\text { with help of PAT \& IADS } \\
\text { tools. }\end{array}$ & $\begin{array}{l}\text { Category-2 } \\
\text { (Skin Condition- } \\
\text { Redness } \\
\text { with } \\
\text { moderate to } \\
\text { severe skin } \\
\text { breakdown) }\end{array}$ & $\begin{array}{l}\text { Erythema, } \\
\text { Edema, } \\
\text { Vesicles/ } \\
\text { Bullae/Skin } \\
\text { erosions, } \\
\text { Skin denudation, } \\
\text { infection }\end{array}$ & $\begin{array}{l}\text { Treatment, management \& } \\
\text { Prevention will be as per Category } \\
\text { - } 0 \text { \& } 1 \text { along with following : } \\
\text { - Antifungal products should be } \\
\text { used only when a cutaneous } \\
\text { fungal rash is present. } \\
\text { - Apply a zinc oxide-based powder for weepy } \\
\text { or bleeding areas } 3 \text { times a day and whenever } \\
\text { stooling occurs. } \\
\text { - Do not scrub the zinc oxide paste completely off } \\
\text { with the next cleaning. } \\
\text { - Gently wipe stool, then apply new paste } \\
\text { covered dressing to area } \\
\text { - Position the person semi prone to } \\
\text { expose affected skin to air. } \\
\text { - Consider treatments that reduce moisture } \\
\text { - Turning, astringents (calamine lotion). } \\
\text { - If condition is very critical consult } \\
\text { concern physician } \\
\text { - If there is Skin infection then take a } \\
\text { microbiological sample } \\
\text { - Use that sample result to decide on } \\
\text { appropriate therapy (e.g. antifungal } \\
\text { cream, topical antibiotic, } \\
\text { anti-inflammatory product) }\end{array}$ \\
\hline
\end{tabular}

Fig. 4: Protocol on prevention and management of IAD.

Flowchart 1: Algorithm of prevention and management of IAD.

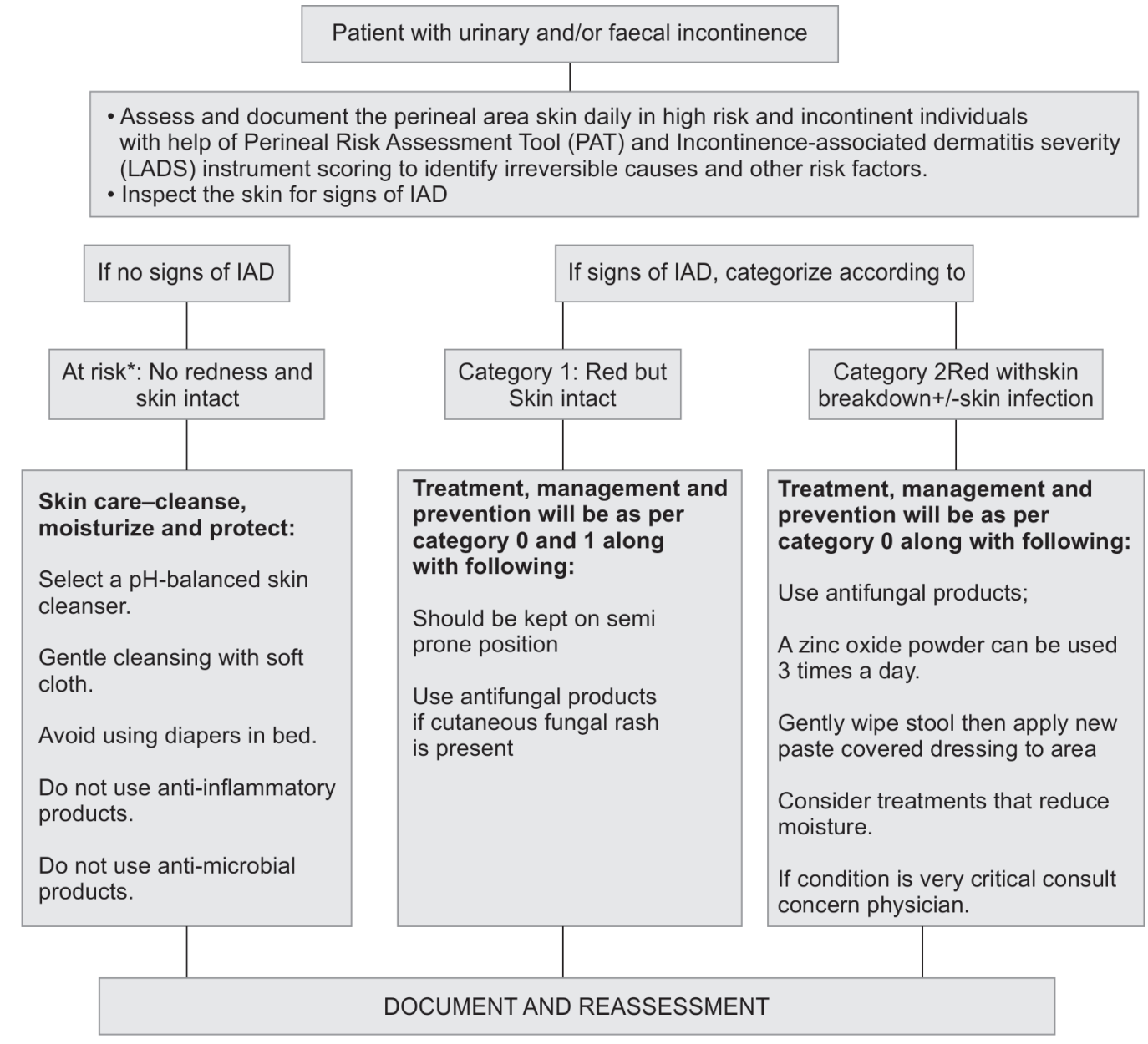




\section{Section-3: Association between Baseline Knowledge and Practice with Selected Variables}

In this study to find the association between the baseline knowledge score and demographic characteristics, Fisher exact and Chi-square tests were used. The obtained ' $p$ ' values were $>0.05$ and hence there was no association between the demographic characteristics and the knowledge score at the $5 \%$ level of significance.

A contradictory cross-sectional study is conducted by "Heidari and Shahbazi" taking 85 staff nurses. The study results explore that there is a significant association between knowledge and gender of nurses $(p<0.05){ }^{6}$

The Fisher exact test was used to find the association between the reported practices and educational status of the staff nurses. The obtained ' $p$ ' value was $<0.05$ only for items 12,13 , and 14 . Hence, these practices were associated with the level of educational status; for all other comparisons, the ' $p$ ' values were $>0.05$ and hence there was no association between those practices and educational status.

According to a similar study which is conducted by "Lien et al." taking 339 hospital staff, it revealed that most of the study participants had good or adequate knowledge though the level of practice is not completely satisfactory. ${ }^{7}$

\section{Section-4: Association between the Risk of IAD and Selected Variables}

In this study to find the association between the risk of IAD and demographic characteristics, likelihood ratio and chi-square test were used. The obtained ' $p$ ' values were $<0.05$ and hence there was an association of age and educational status with risk of IAD, and there was no association of gender, religion, and marital status with risk of IAD.

A similar cohort study conducted by "Chianca et al." taking 157 critically ill patients has revealed that there is an association between age and the risk of IAD $(p<0.015)$. In this study, most of the IAD patients are males (85-54.1\%) and age between 43 and 77 years. ${ }^{8}$

\section{Conclusion}

Based on literature review and study findings, a need-based protocol was developed as described in Figures 3 and 4 and Flowchart 1 which will help to prevent IAD and can be applied in intensive care units for patient care.

\section{OrCID}

Prashant Sharma 우 https://orcid.org/0000-0001-9080-1001

Latha Sambatra (1) https://orcid.org/0000-0003-3029-0267

Rajesh K Sharma ำ https://orcid.org/0000-0002-1000-5521

\section{References}

1. Adult Briefs [Internet]. [cited 2018 Feb 6]. Available from: http://www. covidien.com/incontinence/pages.aspx?page=Adult\%20Briefs.

2. Incontinence Associated Dermatitis [Internet]. [cited 2018 Feb15]. Available from: http://www.pfiedler.com/ce/1205/files/ assets/common/downloads/Incontinence $\% 20$ Associated $\% 20$ Dermatitis.pdf.

3. Gray M, Giuliano KK. Incontinence-associated dermatitis, characteristics and relationship to pressure injury: a multisite epidemiologic analysis. J Wound Ostomy Continence Nurs 2018;45(1):63-67. DOI: 10.1097/WON.0000000000000390.

4. Beeckman D, Defloor T, Schoonhoven L, Vanderwee K. Knowledge and attitudes of nurses on pressure ulcer prevention: a crosssectional multicenter study in Belgian hospitals. Worldviews Evid Based Nurs 2011;8(3):166-176. DOI: 10.1111/j.1741-6787.2011. 00217.x.

5. Altura-Visan F, Zakaria A, Castro J, Alhasanat O, Al Ismail K, Al Ansari N, et al. SWITCH: Al Wakra Hospital journey to $90 \%$ hand hygiene practice compliance, 2011-2015. BMJ Qual Improv Rep 2017;6(1):u211699. w4824. DOI: 10.1136/bmjquality.u211699.w4824.

6. Heidari M, Shahbazi S. Nurses' awareness about principles of airway suctioning. J Clin Diagn Res 2017;11(8):LC17-LC19. DOI: 10.7860/ JCDR/2017/25550.10452.

7. Lien LTQ, Chuc NT, Hoa NQ, Lan PT, Thoa NT, Riggi E, et al. Knowledge and self-reported practices of infection control among various occupational groups in a rural and an urban hospital in Vietnam. Sci Rep 2018;8(1):5119. DOI: 10.1038/s41598-018-23462-8.

8. Chianca TC, Gonçales PC, Salgado PO, Machado BD, Amorim GL, Alcoforado CL. Incontinence-associated dermatitis: a cohort study in critically ill patients. Rev Gaucha Enferm 2017;37(10):e68075. DOI: 10.1590/1983-1447.2016.esp.68075.

9. Graham J. An 'emotional burden' rarely discussed. New York Times. Retrieved August 23, 2014.

10. Kaiser AM. ASCRS core subjects: fecal incontinence. ASCRS. Archived from the original on 20 May 2013.

11. Shah BJ, Chokhavatia S, Rose S. Fecal incontinence in the elderly: FAQ. Am J Gastroenterol 2012;107(11):1635-1646. DOI: 10.1038/ ajg.2012.284. 